\title{
1 GWAS of stool frequency reveals genes, pathways, and cell types 2 relevant to human gastrointestinal motility and irritable bowel 3 syndrome
}

Ferdinando Bonfiglio ${ }^{1,2}$, Xingrong Liu ${ }^{2,3},{ }^{*}$ Christopher Smillie ${ }^{4}$ * Anita Pandit ${ }^{5},{ }^{*}$ Alexander Kurilshikov ${ }^{6}$, Rodrigo Bacigalupe ${ }^{7,8},{ }^{*}$ Tenghao Zheng ${ }^{1,2,3}$, Hieu Nim ${ }^{1}$, Koldo GarciaEtxebarria $^{9}$, Luis Bujanda, ${ }^{9,11}$, Anna Andreasson ${ }^{12}$, Lars Agreus ${ }^{13}$, Susanna Walter ${ }^{14}$, Goncalo Abecasis ${ }^{5}$, Chris Eijsbouts ${ }^{15,16}$, Luke Jostins ${ }^{17,18}$, Miles Parkes ${ }^{19}$, David A Hughes $^{20,21}$, Nicholas Timpson ${ }^{20,21}$, Jeroen Raes ${ }^{7,8}$, Andre Franke ${ }^{22}$, Nicholas A Kennedy ${ }^{23}$, Aviv Regev" \# Alexandra Zhernakova ${ }^{6, "}$ Magnus Simren ${ }^{24, \#}$ Michael Camilleri' ${ }^{25, "}$ Mauro D’Amato ${ }^{1,2,9,26, \S}$

*equal contribution

\#equal contribution

$\S_{\text {corresponding author }}$

${ }^{1}$ School of Biological Sciences, Monash University, Clayton VIC, Australia; ${ }^{2}$ Unit of Clinical Epidemiology, Department of Medicine Solna, Karolinska Institutet, Stockholm, Sweden; ${ }^{3}$ Center for Molecular Medicine, Karolinska Institutet, Stockholm, Sweden; ${ }^{4}$ Klarman Cell Observatory, Broad Institute, Cambridge, MA, USA; ${ }^{5}$ Department of Biostatistics, University of Michigan, School of Public Health, Ann Arbor, MI, USA; ${ }^{6}$ Department of Genetics, University of Groningen, University Medical Center Groningen, Groningen, the Netherlands; ${ }^{7}$ Department of Microbiology and Immunology, Rega Instituut, KU Leuven, Leuven, Belgium; ${ }^{8}$ Center for Microbiology, VIB, Leuven, 3000, Belgium.; ${ }^{9}$ Department of Gastrointestinal and Liver Diseases, Biodonostia HRI, San Sebastián, Spain; ${ }^{10}$ Centro de Investigación Biomédica en Red de Enfermedades Hepáticas y Digestivas (CIBERehd); ${ }^{11}$ Universidad del País Vasco (UPV/EHU), San Sebastian, Spain; ${ }^{12}$ Division of Clinical Medicine, Department of Medicine Solna, Karolinska Institutet, Stockholm, Sweden; ${ }^{13}$ Division of Family Medicine and Primary Care, Department of Neurobiology, Care Sciences and Society, Karolinska Institutet, Stockholm, Sweden; ${ }^{14}$ Division of Neuro and Inflammation Science, Department of Clinical and Experimental Medicine, Linköping University, Linköping, Sweden; ${ }^{15}$ Wellcome Centre for Human Genetics, Nuffield Department of Medicine, University of Oxford, Oxford, UK; ${ }^{16} \mathrm{Big}$ Data Institute, Li Ka Shing Centre for Health Information and Discovery, University of Oxford, Oxford, UK; ${ }^{17}$ Kennedy Institute of Rheumatology, University of Oxford, Oxford, UK; ${ }^{18}$ Christ Church, University of Oxford, Oxford, UK; ${ }^{19}$ Division of Gastroenterology, Department of Medicine, University of Cambridge, UK; ${ }^{20} \mathrm{MRC}$ Integrative Epidemiology Unit at University of Bristol, Bristol, UK; ${ }^{21}$ Population Health Sciences, Bristol Medical School, University of Bristol, Bristol, UK; ${ }^{22}$ Institute of Clinical Molecular Biology, Christian-Albrechts-University of Kiel, Kiel, Germany; ${ }^{23}$ IBD Pharmacogenetics, College of Medicine and Health, University of Exeter, Exeter, UK; ${ }^{24}$ Dept of Internal Medicine \& Clinical Nutrition, Institute of Medicine, Sahlgrenska Academy, University of Gothenburg, Gothenburg, Sweden; ${ }^{25}$ Clinical Enteric Neuroscience Translational and Epidemiological Research (CENTER), and Division of Gastroenterology and Hepatology, Department of Medicine, Mayo Clinic, Rochester, MN, USA; ${ }^{26}$ IKERBASQUE, Basque Foundation for Science, Bilbao, Spain.

\section{Correspondence:}

Mauro D'Amato

School of Biological Sciences, Monash University

25 Rainforest Walk, 3800 Clayton VIC, Australia

+61399053751; mauro.damato@monash.edu

Word count: 3998 
medRxiv preprint doi: https://doi.org/10.1101/2020.06.17.20132555; this version posted June 19, 2020. The copyright holder for this preprint (which was not certified by peer review) is the author/funder, who has granted medRxiv a license to display the preprint in perpetuity.

It is made available under a CC-BY-NC-ND 4.0 International license .

\section{ABSTRACT}

52 Objective. Gut dysmotility is associated with constipation, diarrhea, and functional 53 gastrointestinal disorders (FGID) like irritable bowel syndrome (IBS). Its molecular 54 underpinnings, and their anomalies in FGID disorders are poorly characterized, hence we 55 sought to gain mechanistic insight through a large-scale genetic investigation.

56 Design. We used stool frequency (STL-FRQ) as a (surrogate) quantitative trait to study the 57 genetics of gut motility, exploiting questionnaire and genotype data from UK Biobank and four smaller population-based cohorts (LifeLines-Deep, Genes for Good, Flemish Gut Flora Project and PopCol), in a GWAS meta-analysis spanning $8,817,117$ high-quality SNP 60 markers and 167,875 individuals of European descent.

61 Results. We identify 13 genome-wide significant loci $\left(\mathrm{P} \leq 5.0 \times 10^{-8}\right)$ harboring prioritized genes that are: i) involved in sensory perception and neurotransmitter/neuropeptide signaling; ii) enriched for their expression in enteric motor neurons associated with the control of peristalsis $\left(P=7.0 \times 10^{-8}\right)$ iii) previously linked to other traits and conditions, including

65 GI motility and dysmotility syndromes, and the response to their pharmacological treatment.

66 The genetic architecture of STL-FRQ most strongly correlates with that of IBS $\left(r_{g}=0.42\right.$;

$67 \mathrm{P}=1.1 \times 10^{-3}$ ). In UK Biobank, the risk of IBS with diarrhea was $4 \mathrm{x}$ higher in individuals from 68 the top $1 \%$ of the distribution of polygenic scores (PGS) computed based on STL-FRQ GWAS summary statistics $\left(\mathrm{ORs}=4.14 ; \mathrm{P}=1.2 \times 10^{-97}\right)$.

Conclusion. We identify loci harboring genes with a plausible role in GI motility, possibly 71 acting via neurotransmission and similar pathways in specialized enteric neurons. The demonstrated relevance of these findings to IBS warrants further study for the identification of actionable pathomechanisms in the dysmotility syndromes.

Keywords. Intestinal motility, genetics, irritable bowel syndrome 
medRxiv preprint doi: https://doi.org/10.1101/2020.06.17.20132555; this version posted June 19, 2020. The copyright holder for this preprint (which was not certified by peer review) is the author/funder, who has granted medRxiv a license to display the preprint in perpetuity.

It is made available under a CC-BY-NC-ND 4.0 International license .

\section{INTRODUCTION}

77

78 Gastrointestinal (GI) motility is essential to digestion, nutrients absorption and overall 79 human health, including bi-directional host-microbiome interactions.[1,2] Gut dysmotility and altered peristalsis are observed in constipation, diarrhea, and common functional Gl disorders (FGIDs) like irritable bowel syndrome (IBS), which affect a large portion of the population and pose a remarkable socio-economic and healthcare burden.[3,4] While showing considerable symptoms overlap, most FGIDs are associated with some degree of GI motor dysfunction, possibly best exemplified by the observation that colonic transit time is generally delayed in patients with constipation-predominant IBS (IBS-C), and accelerated in patients with diarrheapredominant IBS (IBS-D).[5,6] Dysmotility plausibly represents a key pathogenetic mechanism contributing to several Gl conditions across a continuum ranging from mild symptoms, through functional disorders, and extreme cases of severely impaired peristalsis as observed in chronic idiopathic intestinal pseudo-obstruction.[7] There is only incomplete understanding of the physiological mechanisms regulating intestinal motility, and their perturbation in the dysmotility syndromes. While some medications (opioids, antidepressants, laxative and others) are known to influence Gl motility, intrinsic triggers are generally believed to come from disturbed communication along the gut-brain axis, inflammatory or degenerative processes, and overstimulation of visceral sensory pathways that ultimately affect the gut musculature and local Gl motor function via the enteric nervous system (ENS).[8] Therapeutic options are limited in the dysmotility syndromes, and rely on targeting specific symptoms rather than (currently unknown) underlying mechanisms. Genetic research may reveal biological pathways amenable to therapeutic exploitation, and 
medRxiv preprint doi: https://doi.org/10.1101/2020.06.17.20132555; this version posted June 19, 2020. The copyright holder for this preprint (which was not certified by peer review) is the author/funder, who has granted medRxiv a license to display the preprint in perpetuity.

It is made available under a CC-BY-NC-ND 4.0 International license .

101 some evidence of heritability can be derived for gut motility from previous studies in

102 relation to colonic transit time measured with detectable tracers.[9-11] These

103 studies, however, were largely underpowered to capture reliable genetic effects, as

104 they lacked replication and focused on few DNA variants from individual candidate

105 genes in small cohorts of IBS patients, hence results are not conclusive or

106 transferable to the general population. As of today, no large-scale study has been

107 performed to identify the genetic determinants of gut motility.

108 Direct assessment of Gl motility in humans requires demanding clinical procedures 109 (like transit time scintigraphy or the radiopaque markers method), which are 110 exclusively performed to support patient diagnosis and therapeutic management, and

111 are therefore not suitable for large-scale population-wide genetic surveys.[12]

112 However, stool consistency and, to a lesser extent, stool frequency (STL-FRQ which

113 refers to the number of bowel movements over a period of time) are valuable

114 indicators of bowel function that correlate with colonic transit time, and can be

115 practically recorded based on questionnaire- or diary survey-based

116 approaches.[13,14] These represent therefore practical surrogate tools that can be

117 adopted and scaled for studying GI motility at the population level thanks to their

118 ease of data collection. Precedent for this approach comes, for instance, from a

119 similar strategy recently applied in a genome-wide association study (GWAS) of IBS

120 as self-reported condition from questionnaire data.[15]

121 Here, we leverage data from UK Biobank and four smaller population-based cohorts

122 (LifeLines-Deep, Genes for Good, Flemish Gut Flora Project and PopCol) for a STL-

123 FRQ GWAS meta-analysis across 8,817,117 high-quality single nucleotide

124 polymorphism (SNP) markers in a total of 167,875 individuals of European descent.

125 We identify 13 loci that harbor genes associated with pathways and cell types 
medRxiv preprint doi: https://doi.org/10.1101/2020.06.17.20132555; this version posted June 19, 2020. The copyright holder for this preprint (which was not certified by peer review) is the author/funder, who has granted medRxiv a license to display the preprint in perpetuity. It is made available under a CC-BY-NC-ND 4.0 International license.

126 plausibly involved in the control of GI motility in humans, and provide compelling

127 evidence of the relevance of these findings to IBS. The identification of genetic 128 factors predisposing to altered gut motility may allow early identification of individuals 129 at higher risk of FGID and, more importantly, therapeutically actionable pathways that 130 may be targeted for the delineation of alternative treatment options. 
medRxiv preprint doi: https://doi.org/10.1101/2020.06.17.20132555; this version posted June 19, 2020. The copyright holder for this preprint (which was not certified by peer review) is the author/funder, who has granted medRxiv a license to display the preprint in perpetuity.

It is made available under a CC-BY-NC-ND 4.0 International license .

\section{MATERIALS AND METHODS}

\section{STUDY COHORTS}

134 We studied phenotype and genotype data in 460,734 individuals from 5 population135 based cohorts: UK Biobank (UKBB), LifeLines-DEEP cohort (LLD), The Genes for

136 Good study (GFG), the Flemish Gut Flora Project (FGFP) and the Population-based

137 Colonoscopy (PopCol) study. Health-related information was derived from

138 questionnaires and participants' electronic medical records, with STL-FRQ defined as

139 the number of stool passes per day, after data harmonization. Selected genotype

140 data was also studied in relation to colonic transit time (CTT) in a small cohort of 160

141 IBS patients from Sweden. A detailed description of all cohorts is reported in

142 Supplementary Table 1 and the Supplementary Methods.

\section{GWAS META-ANALYSIS}

145 A common GWAS pipeline was applied to individual cohorts based on mixed linear 146 models and high quality (INFO>0.8) common (MAF>0.01) markers. A fixed-effect

147 meta-analysis based on the inverse-variance weighted method was performed on a 148 total of 167,875 individuals and $8,817,117$ markers. In the analysis of CTT, STL-FRQ

149 GWAS effect alleles were tested for association with linear regression adjusting for 150 age, sex and first 10 principal components. A summary of relevant data, quality 151 control measures, and analytical procedures is reported in the Supplementary 152 Methods.

153

\section{FUNCTIONAL ANNOTATION OF STL-FRQ LOCI}


medRxiv preprint doi: https://doi.org/10.1101/2020.06.17.20132555; this version posted June 19, 2020. The copyright holder for this preprint (which was not certified by peer review) is the author/funder, who has granted medRxiv a license to display the preprint in perpetuity.

It is made available under a CC-BY-NC-ND 4.0 International license .

155 Locus definition and content. Annotation of STL-FRQ loci was done with FUMA

156 v1.3.5 (https://fuma.ctglab.nl/), based on GWAS meta-analysis summary statistics.

157 Independent association signals were identified based on SNP P-value $\left(\leq 5.0 \times 10^{-8}\right)$

158 and linkage disequilibrium (LD) between markers ( $r 2<0.4)$. Association signals were

159 merged into a single locus for LD blocks closer than 250kb apart. Gene content at

160 STL-FRQ loci was annotated based on positional and expression quantitative trait

161 loci (eQTL) mapping, also with FUMA using default parameters and false discovery

162 rate (FDR) $\mathrm{P}<0.05$.

163 Fine mapping. Fine-mapping was performed for the 13 genome-wide significant loci

164 using FINEMAP v1.3,[16] with z-scores from the STL-FRQ GWAS meta-analysis and

165 LD matrices derived from the genotype probabilities (.bgen files) of UK Biobank data.

166 Specific eQTL traits associated with fine mapped SNPs were identified based on

167 data from GTEx v8.[17]

168

169 ENRICHMENT ANALYSES

170 Gene-set and pathway enrichment analyses. Functional enrichment of STL-FRQ

171 associated genes (as from positional and eQTL mapping with FUMA) was evaluated

172 using GeneNetwork v2.0 (www.genenetwork.nl), in relation to KEGG pathways and

173 Gene Ontology (GO) terms, using pre-computed co-regulation Z-scores and a Mann-

174 Whitney U-test with FDR correction. Enrichment of molecular pathways from the

175 REACTOME libraries was tested using PASCAL with STL-FRQ GWAS meta-

176 analysis summary statistics, and default parameters including type I error control.[18]

177 Cell-type enrichment analyses. Look up of STL-FRQ gene expression was done on

178 previously reported single cell RNA-seq (scRNA-seq) and Ribosomes And Intact

179 Single Nucleus isolation (RAISIN) RNA-seq data from human colonic mucosa and 
medRxiv preprint doi: https://doi.org/10.1101/2020.06.17.20132555; this version posted June 19, 2020. The copyright holder for this preprint (which was not certified by peer review) is the author/funder, who has granted medRxiv a license to display the preprint in perpetuity.

It is made available under a CC-BY-NC-ND 4.0 International license .

180 muscularis propria,[19,20] in relation to 76 cell types including immune, stromal and

181 enteric neurons, among others. As described,[20] enteric neurons were partitioned

182 into 5 classes based on the expression of major neurotransmitters/neuropeptides

183 (CHAT, SLC5A7, NOS1, VIP) and other known markers: putative sensory neurons

184 (PSN), interneurons (PIN subsets 1 and 2), secretomotor/vasodilator neurons

185 (PSVN), and excitatory (PEMN subsets 1 and 2) and inhibitory motor neurons (PIMN

186 subsets 1-5). Enrichment tests, comparing the expression of STL-FRQ genes versus

187 background genes in enteric and motor neurons, were conducted using Fisher's

188 Exact test, controlling for type 1 error by FDR adjustment.

189

190

CROSS-TRAIT ANALYSES

191 Lookup of STL-FRQ GWAS signals in other traits. The GWAS catalog[21] and

192 PhenoScanner[22] were screened with STL-FRQ lead SNPs and their high LD

193 proxies $(r 2>0.8)$ in order to highlight associations $\left(P \leq 5.0 \times 10^{-8}\right)$ with other traits.

194 Associations were plotted with Circlize (cran.r-project.org/web/packages/circlize).

195 Genetic correlations. STL-FRQ SNP heritability $\left(h^{2}\right.$ SNP $)$ and genetic correlation $\left(r_{g}\right)$

196 between STL-FRQ and other complex traits were estimated using LD score

197 regression (LDSC v1.0.1),[23] implemented in the CTG-VL platform (vl.genoma.io),

198 which integrates public summary statistics of 1,387 traits from multiple repositories.

199 Tests for statistical significance were FDR adjusted to control for type I errors.

200

201 POLYGENIC SCORE ANALYSES

202 Polygenic scores (PGS) based on a pruning and thresholding approach were built

203 using PRSice-2.[24] Effect estimates and corresponding standard errors from the

204 STL-FRQ GWAS meta-analysis were used as the base dataset to generate weights, 
medRxiv preprint doi: https://doi.org/10.1101/2020.06.17.20132555; this version posted June 19, 2020. The copyright holder for this preprint (which was not certified by peer review) is the author/funder, who has granted medRxiv a license to display the preprint in perpetuity. It is made available under a CC-BY-NC-ND 4.0 International license.

205 and then applied to IBS traits from UK Biobank (including subtypes) to derive PGS

206 using PRSice-2 default settings. To account for the differences in the numbers of

207 variants per cohort, a normalized polygenic score (mean=0, SD=1) was created per

208 cohort. Student's t-test was employed to determine the significance of the difference

209 between the mean PGSs in IBS and controls. PGSs were binned into percentiles and

210 the subset of IBS patients within a given magnitude of increased STL-FRQ PGS (top

211 percentiles) was compared to the reminder of the population in a logistic regression

212 adjusting for sex, age, the first 10 PCs and genotyping array. 
medRxiv preprint doi: https://doi.org/10.1101/2020.06.17.20132555; this version posted June 19, 2020. The copyright holder for this preprint (which was not certified by peer review) is the author/funder, who has granted medRxiv a license to display the preprint in perpetuity.

It is made available under a CC-BY-NC-ND 4.0 International license .

\section{RESULTS}

\section{STL-FRQ GWAS meta-analysis}

216 The distribution of STL-FRQ (harmonized to the number of stool passes per day) was 217 similar in the studied cohorts, with average ranging from 1.12 in GFG to 1.42 in

218 UKBB and PopCol. Independent GWAS were carried out in individual cohorts using a common pipeline (Supplementary Methods), and later included in a meta-analysis encompassing 167,875 participants and $8,817,117$ high-quality SNP markers. The

STL-FRQ GWAS meta-analysis showed no population stratification (LDSC intercept = 1.02, see Methods), and identified 3751 genome-wide-significant associations $\left(P=4.8 \times 10^{-21}\right)$, in proximity of the BDNF gene.

\section{Gene-set and pathway enrichment analyses}

228 In order to obtain biological insight from the observed associations, we analysed STL-FRQ GWAS data with a computational pipeline for the functional annotation of associated loci. FUMA was used to define STL-FRQ GWAS loci, their boundaries and respective gene content, based on positional and eQTL mapping (see Methods). Several relevant genes were located at the associated loci (Supplementary Table 2),

233 therefore we proceeded to perform gene-set and pathway enrichment analysis.

234 GeneNetwork analysis revealed significant (FDR $\mathrm{P}<0.01)$ enrichment for relevant KEGG pathways including "neuroactive ligand receptor interaction", and GO terms "detection of chemical stimulus involved in sensory perception" and "neuropeptide 
medRxiv preprint doi: https://doi.org/10.1101/2020.06.17.20132555; this version posted June 19, 2020. The copyright holder for this preprint (which was not certified by peer review) is the author/funder, who has granted medRxiv a license to display the preprint in perpetuity.

It is made available under a CC-BY-NC-ND 4.0 International license .

238 pathway-level analysis highlighted "neurotransmitter receptor binding and

239 downstream transmission in the postsynaptic cell" and "serotonin receptors" as the

240 top enriched REACTOME pathways (Supplementary Table 4).

241

242 Functional annotation at the single cell level

243 STL-FRQ genes did not show any preferential tissue expression based on FUMA or

244 DEPICT analyses (not shown), hence we turned to study cell-type specific

245 expression using single cell transcriptomic data available from human colonic

246 mucosa and muscularis propria.[19,20] Look up of STL-FRQ gene expression was

247 carried out using scRNA-seq and RAISINs RNA-seq data (see Methods), in relation

248 to immune, epithelial, stromal and glial cells, muscle cells, and 11 subtypes of enteric

249 neurons grouped into 5 major classes based on the relative expression of major

250 neurotransmitters neuropeptides and other markers (Figure 3 and Supplementary

251 Figure S2). Of note, the expression of STL-FRQ associated genes was strongly

252 enriched in enteric neurons (FDR $\mathrm{P}=1.4 \times 10^{-3}$ ), and more so in specific putative

253 excitatory and inhibitory motor neurons (PEMN and PIMN subtypes, FDR $\mathrm{P}=7.0 \times 10^{-}$

$254{ }^{8}$ ) reportedly involved in the control of peristalsis.[20] Hence, functional annotation of

255 STL-FRQ genes at the single cell level points to a potential role in controlling human

256 gut motility through the involvement of specialized neuronal populations.

257

258 Prioritization of causative genes

259 FINEMAP analysis of candidate causative SNPs from STL-FRQ loci mapped 4/13 260 signals at single-marker resolution with $>50 \%$ probability (Table 1 ). Variants

261 rs4556017 and rs13162291 were mapped with highest confidence (respective 262 probabilities $95.1 \%$ and $83.5 \%$ ) and are both associated with eQTLs in multiple 
medRxiv preprint doi: https://doi.org/10.1101/2020.06.17.20132555; this version posted June 19, 2020. The copyright holder for this preprint (which was not certified by peer review) is the author/funder, who has granted medRxiv a license to display the preprint in perpetuity.

It is made available under a CC-BY-NC-ND 4.0 International license .

263 tissues (Supplementary Figure S3). In particular, rs4556017 shows eQTLs for the 264 acetylcholinesterase $A C H E$, and rs13162291 eQTLs for the fatty acid hydroxylase 265 FAXDC2, two genes expressed in enteric and motor neurons (Figure 3). The SNP 266 rs11240503 is associated with a colon-specific eQTL for CDK18 (Supplementary 267 Figure S3), a protein kinase expressed in colonic M cells and BEST4+ enterocytes

268 (Figure 3). Finally, the rs12273363 marker is associated with eQTLs for a long non 269 coding antisense RNA (BDNF-AS, Supplementary Figure S3) modulating the 270 expression of the brain-derived neurotrophic factor BDNF.[25] Of note, rs12273363 emerged as top GWAS signal in our meta-analysis $\left(P=4.8 \times 10^{-21}\right.$, Table 1$)$, and was also associated with consistent genetic effects on CTT measured by the radiopaque method in a small set of 160 IBS individuals $(P=0.036$, with the $T$ allele associated both with more frequent stools and faster transit; Table 1 and Supplementary Table 5). Although fine mapping did not highlight most likely causative variants at other loci,

276 their gene content includes candidate genes of known relevance to Gl motility and dysmotility syndromes, like neuropeptides/neurotransmitters and their receptors

278 (CALCA/CALCB, CRHR1), ion channels (KCNJ4), tight junction proteins (CLDN15) and others (Supplementary Table 2). Genetic variation at these loci also appears to affect gene expression across several tissues, as evidenced by eQTL analysis

281 (Supplementary Figure S4).

282

283 Correlations with other disease and traits

284 A lookup of STL-FRQ association signals in publicly available GWAS data suggested some of the 13 loci to be relevant to other traits and diseases across multiple domains, including health outcomes, lifestyle factors and anthropometric traits

287 (Figure 4A). In particular, the loci tagged by markers rs12273363 and rs2732706 
medRxiv preprint doi: https://doi.org/10.1101/2020.06.17.20132555; this version posted June 19, 2020. The copyright holder for this preprint (which was not certified by peer review) is the author/funder, who has granted medRxiv a license to display the preprint in perpetuity.

It is made available under a CC-BY-NC-ND 4.0 International license .

288 showed the largest number of associations, mostly with anthropometric and

289 psychiatric traits, respectively (Supplementary Table 6).

290 Evidence of genetic correlation with other conditions and traits was obtained from

291 broader analyses of STL-FRQ GWAS summary statistics using LDSC analysis,

292 which estimated SNP-based STL-FRQ heritability around 7\% $\left(h^{2}\right.$ SNP=0.073). When

293 screening publicly available GWAS data (see Methods), strongest correlation was

294 observed for IBS $\left(r_{g}=0.42\right.$, FDR $\left.P=5.1 \times 10^{-5}\right)$, while additional significant findings were

295 obtained for other gastrointestinal (diverticular disease, use of proton pump inhibitors

296 - Omeprazole) and psychiatric (anxiety, depression) traits, as well as a number of

297 traits associated with pain and fatigue (Figure 4B and Supplementary Table 7),

298 comorbidities often seen in dysmotility syndromes like IBS. Typifying inverse

299 correlations were also detected for dietary fibers (bran cereals) and laxatives

300 (dulcolax), which are usually consumed to avoid or relieve constipation, indeed a trait

301 at or near the root of the STL-FRQ distribution tested here.

302

303 STL-FRQ polygenic scores and irritable bowel syndrome

304 We further explored the relevance of STL-FRQ GWAS findings to IBS by computing

305 PGS with PRSice-2 (see Methods) using STL-FRQ GWAS summary statistics. We

306 studied STL-FRQ PGS in relation to IBS and its subtypes (constipation, IBS-C;

307 diarrhea, IBS-D and mixed, IBS-M) defined according to gold-standard consensus

308 Rome III criteria,[26] using data available for a subset of 164,979 UK Biobank

309 participants who filled a digestive health questionnaire (the same used for the

310 derivation of STL-FRQ in UK Biobank, Supplementary Methods). PGS distribution

311 was significantly different in IBS vs asymptomatic individuals, most pronouncedly for

312 IBS-D (mean PGS 0.456 vs -0.022 in cases and controls; $P<1 \times 10^{-300}$ ) (Figure 5). 
medRxiv preprint doi: https://doi.org/10.1101/2020.06.17.20132555; this version posted June 19, 2020. The copyright holder for this preprint (which was not certified by peer review) is the author/funder, who has granted medRxiv a license to display the preprint in perpetuity.

It is made available under a CC-BY-NC-ND 4.0 International license .

313 IBS-D prevalence increased from $2.9 \%$ in the lowest to $16.4 \%$ in the highest PGS

314 percentile, with individuals showing markedly increased IBS-D risk towards the tail of

315 PGS distribution (ORs 4.14; $P=1.2 \times 10^{-97}$ for the top $1 \%$ and ORs $2.88 ; P=3.1 \times 10^{-209}$

316 for the top 5\% of the distribution, respectively; Figure 5 and Supplementary Table 8).

317 However, although focused on a different trait (IBS), these analyses were performed

318 on UK Biobank participants also included in the STL-FRQ GWAS (97\% overlap),

319 hence we further tested STL-FRQ PGS in the independent remainder of UK Biobank

$320(\mathrm{~N}=291,496)$, in relation to combined IBS diagnoses available from touchscreen

321 questionnaire (self-reported) and electronic medical records (ICD10 codes) (see

322 Supplementary Methods). Although the prevalence of IBS defined by this approach

323 was much lower (3.3\%), and the diarrhea or other IBS subtypes could not be tested,

324 similar results were obtained, thus replicating Rome-III findings: PGS values were

325 significantly higher in cases than controls (respective means 0.042 and -0.001 ;

$\left.326 \mathrm{P}=2.9 \times 10^{-5}\right)$, IBS prevalence increased across PGS percentiles (3.6-4.2\% bottom-top

327 percentile range) and the risk of IBS was highest in the top $1 \%$ of the PGS

328 distribution (1.29 OR; $\mathrm{P}=6.7 \times 10^{-3}$; Supplementary Table 8). 
medRxiv preprint doi: https://doi.org/10.1101/2020.06.17.20132555; this version posted June 19, 2020. The copyright holder for this preprint (which was not certified by peer review) is the author/funder, who has granted medRxiv a license to display the preprint in perpetuity.

It is made available under a CC-BY-NC-ND 4.0 International license .

\section{DISCUSSION}

331 We report the results of a powered STL-FRQ GWAS, based on the meta-analysis of

332 genetic and health-related data from five population-based cohorts. We undertook

333 this study because of the known correlation between stool frequency and gut motility,

334 whereas the latter cannot be feasibly studied in humans in numbers large enough for

335 meaningful genetic investigations. Our approach therefore aimed at revealing

336 relevant physiological pathways and mechanisms via indirectly measuring GI function

337 based on suitable questionnaire data on bowel habits. A similar strategy was adopted

338 in a previous study, however no significant results were obtained, likely due to the

339 small size of the cohorts analyzed (total $N=1281$ ).[27] Studying almost 170,000

340 individuals, here we identify thousands of associations from 13 independent genome-

341 wide significant loci, which harbor genes and DNA variants implicating pathways, cell

342 types and mechanisms plausibly affecting human gut motility in health and disease.

343 Functional annotation and GWAS-downstream analyses suggest that genes from

344 STL-FRQ loci are largely involved in neuropeptide and neurotransmitter signaling,

345 sensory perception and control of motor function in the gut, which provides further

346 evidence of the validity of our approach. These pathways are notoriously central to

347 the ENS and its effects on GI motility, enabling bidirectional communication along the

348 gut-brain axis.[28] Neuropeptides and neurotransmitters regulate gut behavior by

349 propagating neuronal signals to the mucosal, immune and muscle systems, with

350 excitatory and inhibitory effects on muscle contraction and peristalsis, among other

351 functions. Our gene expression and cell-type enrichment analyses provide additional

352 insight by harnessing the power of single-cell transcriptomics: exploiting RAISIN data

353 from human colonic muscularis propria, we reveal how STL-FRQ genes are strongly 
medRxiv preprint doi: https://doi.org/10.1101/2020.06.17.20132555; this version posted June 19, 2020. The copyright holder for this preprint (which was not certified by peer review) is the author/funder, who has granted medRxiv a license to display the preprint in perpetuity.

It is made available under a CC-BY-NC-ND 4.0 International license .

354 enriched for their expression in enteric neurons, a specific pattern otherwise 355 undetected at the whole tissue level. In particular, the enrichment appears to be more 356 pronounced in putative excitatory and inhibitory motor neurons that have been

357 associated with peristalsis and mechanosensation of gut distention (PEMN and PIMN 358 subtypes expressing the mechanosensitive ion channel PIEZO2).[20] Further 359 investigation of such expression patterns, coupled with functional characterization of 360 STL-FRQ genes in specialized cell types and neuronal subtypes, may therefore 361 contribute important insight into the exact mechanisms underlying neurogenic motor 362 control in the gut, including dissecting specific classes of ENS neurons into their 363 respective functional roles. This may aid the development of future therapeutic 364 strategies to modify Gl function and motility.

365 Individual genes most likely candidate to play an important role in the control of STL-

$366 \mathrm{FRQ}$ also clearly point to the involvement of neuropeptide/neurotransimitter signaling

367 pathways. This is best exemplified by the strongest association we detected in our

368 GWAS meta-analysis at the BDNF locus on chromosome 13, which also replicated in

369 CTT analyses of IBS patients. The association signal is mapped with relatively high confidence ( $>50 \%$ probability) to the rs12273363 marker, which is linked to multiple

371 functional effects on BDNF expression: it has eQTL effects on an antisense 372 transcript (BDNF-AS) that induces BDNF mRNA degradation,[25] and lies in a 373 regulatory region previously shown to impart allele-specific, direct repression of $374 B D N F$ promoter activity (with rs12273363 T a less active repressor).[29] $B D N F$ is a 375 neurotrophin expressed in the central and peripheral nervous systems, with 376 neurotransmitter modulatory properties and a crucial role in neuronal growth, 377 differentiation, survival and plasticity.[30] It has also been implicated in several 378 diseases including major depression, bipolar disorder and other psychiatric 
medRxiv preprint doi: https://doi.org/10.1101/2020.06.17.20132555; this version posted June 19, 2020. The copyright holder for this preprint (which was not certified by peer review) is the author/funder, who has granted medRxiv a license to display the preprint in perpetuity.

It is made available under a CC-BY-NC-ND 4.0 International license .

379 conditions.[31] BDNF is recognized to influence many important gut functions,

380 including sensation, motility, epithelial barrier, neuroprotection, and 381 neuroplasticity.[32] Multiple lines of evidence indicate BDNF has prokinetic effects on

382 gut motility, as shown by impaired peristalsis and delayed Gl transit in $B D N F+/-$

383 mice,[33] increased colonic myoelectric activity in BDNF-treated rats,[34] reduced

384 BDNF colonic levels in patients with slow-transit constipation[35] and, notably,

385 accelerated $\mathrm{Gl}$ and colonic transit in individuals administered recombinant $B D N F(\mathrm{r}-$

386 metHuBDNF).[36] Hence, our findings are in line with these observations, in that the

387 rs12273363 T allele associated with more frequent stools and shorter CTT has also

388 been shown to induce stronger BDNF expression (weaker repressor).[29] Altogether,

389 this suggests a bona fide role for BDNF in the genetically-determined modulation of

390 human gut motility, and warrants new analyses of recombinant $B D N F$ trials based on

391 genotype stratification.

392 Our results also point to interesting candidate genes from other STL-FRQ loci where

393 the association signal has been refined: $A C H E, F A X D C 2$ and $C D K 18$ all show eQTLs

394 association with individual variants that have been fine mapped with $>50 \%$ probability

395 (respectively, rs4556017 on chromosome 7, rs13162291 on chromosome 5 and

396 rs11240503 on chromosome 1). ACHE codes for an enzyme that hydrolyzes the

397 neurotransmitter acetylcholine at neuromuscular junctions and is overexpressed in

398 Hirschsprung's disease,[37] while FAXDC2 is a hydroxylase of fatty acids whose

399 Iuminal concentrations are known to affect gut motility;[38,39] they are both

400 expressed in enteric and motor neurons and therefore represent ideal functional

401 candidates. CDK18 encodes a protein kinase expressed in colonic $\mathrm{M}$ cells and

402 BEST4+ enterocytes specialized in electrolyte and $\mathrm{pH}$ sensing,[20,40] hence its 
medRxiv preprint doi: https://doi.org/10.1101/2020.06.17.20132555; this version posted June 19, 2020. The copyright holder for this preprint (which was not certified by peer review) is the author/funder, who has granted medRxiv a license to display the preprint in perpetuity.

It is made available under a CC-BY-NC-ND 4.0 International license .

403 associated colon-specific eQTL may be relevant to colonic osmolarity and, 404 consequently, transit.

405 Finally, strong functional candidates with a well-known role in Gl motility map to 406 additional loci where the association could not be attributed to specific variants.

407 These involve additional neuropeptides/neurotransmitter systems, including alpha 408 and beta calcitonin-gene related peptides (CALCA and CALCB genes) from the 409 rs6486216 locus,[41] and the corticotropin-releasing hormone receptor (CRHR1) 410 from the rs2732706 locus.[42] Altogether, these and previous observations made for 411 STL-FRQ candidate causative genes are particularly interesting, in that they may 412 provide rationale for future translational opportunities in the dysmotility syndromes.

413 Several STL-FRQ associations were previously detected also in other health and 414 disease-related traits, as from our cross-trait approach to interrogating publicly 415 available GWAS data. Ten out of thirteen GWAS loci were already linked to lifestyle, 416 anthropometric and disease-related traits (psychiatric conditions in particular).

417 Broader evidence of genetic overlap with these conditions came from our LDSC 418 analyses, which further highlighted shared genetic architecture with gastrointestinal 419 diseases and often co-morbid neuroaffective traits,[43] among others. This likely 420 reflects the recognized importance of the gut-brain axis, and suggests our results 421 may be exploited to gain disease insight in addition to their relevance to better 422 understanding the physiology of human gut motility. We explored this in relation to 423 IBS, the most common FGID and the archetype of dysmotility syndromes, which also 424 showed strongest correlation with STL-FRQ among all traits tested in the LDSC 425 analysis.

426 Polygenic scores (PGS; calculated by summing multiple alleles weighted by their 427 effect sizes, usually derived from GWAS studies), are an attractive way to capture an 
medRxiv preprint doi: https://doi.org/10.1101/2020.06.17.20132555; this version posted June 19, 2020. The copyright holder for this preprint (which was not certified by peer review) is the author/funder, who has granted medRxiv a license to display the preprint in perpetuity.

It is made available under a CC-BY-NC-ND 4.0 International license .

428 individual's predisposition to develop a specific trait or disease, and hold strong

429 potential for clinical translation and patient stratification. We computed PGS based on

430 our STL-FRQ GWAS meta-analysis, and tested them in relation to IBS in the large

431 UK Biobank cohort. STL-FRQ PGS were significantly higher in IBS cases vs

432 asymptomatic controls defined according to Rome III criteria available for

433 approximately 165,000 individuals, as well as in individuals with a doctor's diagnosis

434 of IBS (self-reported or in their medical records) compared to all other participants in

435 the remainder of UK Biobank (almost 300,000 people). Individuals from the upper tail

436 of the PGS distribution were more likely affected by IBS, and exposed to up to $>4 \mathrm{x}$

437 higher risk of IBS-D compared to the rest of the population (in the top $1 \%$ of the

438 distribution). Of note, at least in UK Biobank, the heritability of STL-FRQ

$439\left(h^{2}{ }_{S N P}=0.073\right)$ appears to be higher than that of IBS $\left(h^{2}{ }_{S N P}=0.037\right.$ on the liability

440 scale, based on previous GWAS data on self-reported IBS).[15] This suggests that,

441 once refined and further validated in independent cohorts, PGS derived from the

442 simple STL-FRQ trait may ultimately contribute to an early identification, and

443 eventual preventive treatment, of individuals at higher risk of developing IBS and

444 other complex dysmotility syndromes.

445 Finally, our study has a number of limitations: i) stool frequency defined according to

446 questionnaire data only equates to human gut motility to a certain extent, as its

447 correlation with GI transit time has been shown to be weaker than, for instance, stool

448 consistency; ii) current analyses could not take into account likely contributing

449 environmental factors like diet, medications and others (whose related information

450 was unavailable in most datasets); iii) relevant cell types and neuronal species have

451 been identified and further classified here based on gene expression data, hence

452 functional characterizations may be necessary to confirm specific mechanisms 
medRxiv preprint doi: https://doi.org/10.1101/2020.06.17.20132555; this version posted June 19, 2020. The copyright holder for this preprint (which was not certified by peer review) is the author/funder, who has granted medRxiv a license to display the preprint in perpetuity. It is made available under a CC-BY-NC-ND 4.0 International license.

453 involved in the control of STL-FRQ and motility, as proposed; and finally iv) most

454 STL-FRQ loci still require conclusive identification of the individual causative gene 455 and variant(s). These issues can be addressed in future studies, and should 456 therefore stimulate further investigation as follow-up to the novel findings reported 457 here.

458 In conclusion, we identify loci harboring prioritized genes with a plausible role in Gl 459 motility, possibly acting via neurotransmission and similar pathways in specialized 460 enteric neurons. The demonstrated relevance of these findings to IBS warrants 461 further study for the identification of actionable pathomechanisms in the dysmotility 462 syndromes. 
medRxiv preprint doi: https://doi.org/10.1101/2020.06.17.20132555; this version posted June 19, 2020. The copyright holder for this preprint (which was not certified by peer review) is the author/funder, who has granted medRxiv a license to display the preprint in perpetuity.

It is made available under a CC-BY-NC-ND 4.0 International license .

463 ACKNOWLEDGEMENTS. This research has been conducted using the UK Biobank 464 Resource under Application Number 17435.

465 AUTHOR CONTRIBUTORSHIP. MD and AZ: study concept and design; AA, LA, 466 SW, GA, MP, DAH, NT, JR, AF, NAK, AR, AZ, MS, MC, MD: cohorts, patients 467 characterization, data collection; FB, XL, CS, AP, AK, RB, TZ, HN, KGE: statistical 468 analyses; FB, XL, CS, AP, AK, RB, LB, CE, LJ, MP, NT, JR, AF, NAK, AR, AZ, MS, 469 MC, MD: data analysis and interpretation; MD: obtained funding, administrative and 470 technical support, study supervision; FB and MD: drafted the manuscript, with input 471 and critical revision from all other authors.

472 COMPETING INTERESTS. None declared.

473 FUNDING. Supported by grants from the Swedish Research Council (VR 2017474 02403), the Health Department of the Basque Government (2015111133), and the 475 Spanish Ministry of Economy and Competitiveness (FIS PI17/00308) to MDA; the 476 research leading to these results has received funding from the EU FP7 under grant 477 nr. 313010 (BBMRI-LPC); the FGFP project received support from the Flemish 478 government (IWT130359), the Research Fund-Flanders (FWO) Odysseus program 479 (G.0924.09), the King Baudouin Foundation (2012-J80000-004), FP7 METACARDIS 480 HEALTH-F4-2012-305312, VIB, the Rega Institute for Medical Research, and KU 481 Leuven. RB is funded by the Research Fund-Flanders (FWO) through a Postdoctoral 482 Fellowship (1221620N). AZ is supported by the ERC Starting Grant 715772, 483 Netherlands Organization for Scientific Research NWO-VIDI grant 016.178.056, the 484 Netherlands Heart Foundation CVON grant 2018-27, and the NWO Gravitation grant 485 ExposomeNL 024.004.017. 
medRxiv preprint doi: https://doi.org/10.1101/2020.06.17.20132555; this version posted June 19, 2020. The copyright holder for this preprint (which was not certified by peer review) is the author/funder, who has granted medRxiv a license to display the preprint in perpetuity.

It is made available under a CC-BY-NC-ND 4.0 International license .

486 REFERENCES

487

488

489

490

491

492

493

494

495

496

497

498

499

500

501

502

503

504

505

506

507

508

509

510

511

512

513

514

515

516

517

518

519

520

521

522

523

524

525

1 Scratcherd T, Grundy D. The physiology of intestinal motility and secretion. Br J Anaesth 1984;56:3-18. doi:10.1093/bja/56.1.3

2 Quigley EMM. Microflora modulation of motility. J Neurogastroenterol Motil 2011;17:1407. doi:10.5056/jnm.2011.17.2.140

3 Keller J, Bassotti G, Clarke J, et al. Expert consensus document: Advances in the diagnosis and classification of gastric and intestinal motility disorders. Nat Rev Gastroenterol Hepatol 2018;15:291-308. doi:10.1038/nrgastro.2018.7

4 Simrén M, Tack J. New treatments and therapeutic targets for IBS and other functional bowel disorders. Nat Rev Gastroenterol Hepatol 2018;15:589-605. doi:10.1038/s41575018-0034-5

5 Manabe N, Wong BS, Camilleri M, et al. Lower functional gastrointestinal disorders: evidence of abnormal colonic transit in a 287 patient cohort. Neurogastroenterol Motil 2010;22:293-e82. doi:10.1111/j.1365-2982.2009.01442.x

6 Törnblom H, Van Oudenhove L, Sadik R, et al. Colonic transit time and IBS symptoms: what's the link? Am J Gastroenterol 2012;107:754-60. doi:10.1038/ajg.2012.5

7 Knowles $\mathrm{CH}$, Lindberg G, Panza E, et al. New perspectives in the diagnosis and management of enteric neuropathies. Nat Rev Gastroenterol Hepatol 2013;10:206-18. doi:10.1038/nrgastro.2013.18

8 Boeckxstaens G, Camilleri M, Sifrim D, et al. Fundamentals of Neurogastroenterology: Physiology/Motility - Sensation. Gastroenterology 2016;150:1292-1304.e2. doi:10.1053/j.gastro.2016.02.030

9 Camilleri M, Shin A, Busciglio I, et al. Genetic variation in GPBAR1 predisposes to quantitative changes in colonic transit and bile acid excretion. Am J Physiol Gastrointest Liver Physiol 2014;307:G508-516. doi:10.1152/ajpgi.00178.2014

10 Camilleri M, Carlson P, Zinsmeister AR, et al. Neuropeptide S receptor induces neuropeptide expression and associates with intermediate phenotypes of functional gastrointestinal disorders. Gastroenterology 2010;138:98-107.e4. doi:10.1053/j.gastro.2009.08.051

11 Wong BS, Camilleri M, Carlson PJ, et al. A Klotho $\beta$ variant mediates protein stability and associates with colon transit in irritable bowel syndrome with diarrhea. Gastroenterology 2011;140:1934-42. doi:10.1053/j.gastro.2011.02.063

12 Fox MR, Kahrilas PJ, Roman S, et al. Clinical measurement of gastrointestinal motility and function: who, when and which test? Nat Rev Gastroenterol Hepatol 2018;15:56879. doi:10.1038/s41575-018-0030-9

13 Jaruvongvanich V, Patcharatrakul T, Gonlachanvit S. Prediction of Delayed Colonic Transit Using Bristol Stool Form and Stool Frequency in Eastern Constipated Patients: A Difference From the West. J Neurogastroenterol Motil 2017;23:561-8. doi:10.5056/jnm17022 
medRxiv preprint doi: https://doi.org/10.1101/2020.06.17.20132555; this version posted June 19, 2020. The copyright holder for this preprint (which was not certified by peer review) is the author/funder, who has granted medRxiv a license to display the preprint in perpetuity.

It is made available under a CC-BY-NC-ND 4.0 International license .

14 Saad RJ, Rao SSC, Koch KL, et al. Do stool form and frequency correlate with whole-gut and colonic transit? Results from a multicenter study in constipated individuals and healthy controls. Am J Gastroenterol 2010;105:403-11. doi:10.1038/ajg.2009.612

15 Bonfiglio F, Zheng T, Garcia-Etxebarria K, et al. Female-Specific Association Between Variants on Chromosome 9 and Self-Reported Diagnosis of Irritable Bowel Syndrome. Gastroenterology 2018;155:168-79. doi:10.1053/j.gastro.2018.03.064

16 Benner C, Spencer CCA, Havulinna AS, et al. FINEMAP: efficient variable selection using summary data from genome-wide association studies. Bioinformatics 2016;32:1493-501. doi:10.1093/bioinformatics/btw018

17 GTEx Consortium, Laboratory, Data Analysis \&Coordinating Center (LDACC)_Analysis Working Group, Statistical Methods groups-Analysis Working Group, et al. Genetic effects on gene expression across human tissues. Nature 2017;550:204-13. doi:10.1038/nature24277

18 Lamparter D, Marbach D, Rueedi R, et al. Fast and Rigorous Computation of Gene and Pathway Scores from SNP-Based Summary Statistics. PLoS Comput Biol 2016;12:e1004714. doi:10.1371/journal.pcbi.1004714

19 Smillie CS, Biton M, Ordovas-Montanes J, et al. Intra- and Inter-cellular Rewiring of the Human Colon during Ulcerative Colitis. Cell 2019;178:714-730.e22. doi:10.1016/j.cell.2019.06.029

20 Drokhlyansky E, Smillie CS, Wittenberghe NV, et al. The enteric nervous system of the human and mouse colon at a single-cell resolution. bioRxiv 2019;:746743. doi:10.1101/746743

21 Buniello A, MacArthur JAL, Cerezo M, et al. The NHGRI-EBI GWAS Catalog of published genome-wide association studies, targeted arrays and summary statistics 2019. Nucleic Acids Res 2019;47:D1005-12. doi:10.1093/nar/gky1120

22 Kamat MA, Blackshaw JA, Young R, et al. PhenoScanner V2: an expanded tool for searching human genotype-phenotype associations. Bioinformatics 2019;35:4851-3. doi:10.1093/bioinformatics/btz469

23 Bulik-Sullivan BK, Loh P-R, Finucane HK, et al. LD Score regression distinguishes confounding from polygenicity in genome-wide association studies. Nature Genetics 2015;47:291-5. doi:10.1038/ng.3211

24 Choi SW, O'Reilly PF. PRSice-2: Polygenic Risk Score software for biobank-scale data. Gigascience 2019;8. doi:10.1093/gigascience/giz082

25 Modarresi F, Faghihi MA, Lopez-Toledano MA, et al. Inhibition of natural antisense transcripts in vivo results in gene-specific transcriptional upregulation. Nat Biotechnol 2012;30:453-9. doi:10.1038/nbt.2158

26 Drossman DA. The functional gastrointestinal disorders and the Rome III process. Gastroenterology 2006;130:1377-90. doi:10.1053/j.gastro.2006.03.008

27 Jankipersadsing SA, Hadizadeh F, Bonder MJ, et al. A GWAS meta-analysis suggests roles for xenobiotic metabolism and ion channel activity in the biology of stool frequency. Gut 2017;66:756-8. doi:10.1136/gutjnl-2016-312398 
medRxiv preprint doi: https://doi.org/10.1101/2020.06.17.20132555; this version posted June 19, 2020. The copyright holder for this preprint (which was not certified by peer review) is the author/funder, who has granted medRxiv a license to display the preprint in perpetuity.

It is made available under a CC-BY-NC-ND 4.0 International license .

567

568

569

570

571

572

573

574

575

576

577

578

579

580

581

582

583

584

585

586

587

588

589

590

591

592

593

594

595

596

597

598

599

600

601

602

603

604

605

606
28 Tack J, Berghe PV. Neuropeptides and colonic motility: It's all in the little brain. Gastroenterology 2000;119:257-60. doi:10.1053/gast.2000.9115

29 Hing B, Davidson S, Lear M, et al. A polymorphism associated with depressive disorders differentially regulates brain derived neurotrophic factor promoter IV activity. Biol Psychiatry 2012;71:618-26. doi:10.1016/j.biopsych.2011.11.030

30 Maisonpierre PC, Belluscio L, Friedman B, et al. NT-3, BDNF, and NGF in the developing rat nervous system: Parallel as well as reciprocal patterns of expression. Neuron 1990;5:501-9. doi:10.1016/0896-6273(90)90089-X

31 Di Carlo P, Punzi G, Ursini G. Brain-derived neurotrophic factor and schizophrenia. Psychiatr Genet 2019;29:200-10. doi:10.1097/YPG.0000000000000237

32 Liu S. Neurotrophic factors in enteric physiology and pathophysiology. Neurogastroenterology \& Motility 2018;30:e13446. doi:10.1111/nmo.13446

33 Grider JR, Piland BE, Gulick MA, et al. Brain-derived neurotrophic factor augments peristalsis by augmenting $5-\mathrm{HT}$ and calcitonin gene-related peptide release. Gastroenterology 2006;130:771-80. doi:10.1053/j.gastro.2005.12.026

34 Chai N-L, Dong L, Li Z-F, et al. Effects of neurotrophins on gastrointestinal myoelectric activities of rats. World J Gastroenterol 2003;9:1874-7. doi:10.3748/wjg.v9.i8.1874

35 Chen $\mathrm{F}, \mathrm{Yu} \mathrm{Y}$, Wang $\mathrm{P}$, et al. Brain-derived neurotrophic factor accelerates gut motility in slow-transit constipation. Acta Physiol (Oxf) 2014;212:226-38. doi:10.1111/apha.12374

36 Coulie B, Szarka LA, Camilleri M, et al. Recombinant human neurotrophic factors accelerate colonic transit and relieve constipation in humans. Gastroenterology 2000;119:41-50. doi:10.1053/gast.2000.8553

37 Moore SW, Johnson G. Acetylcholinesterase in Hirschsprung's disease. Pediatr Surg Int 2005;21:255-63. doi:10.1007/s00383-005-1383-z

38 Jin Q, Ren Y, Wang M, et al. Novel function of FAXDC2 in megakaryopoiesis. Blood Cancer Journal 2016;6:e478-e478. doi:10.1038/bcj.2016.87

39 Neunlist M, Schemann M. Nutrient-induced changes in the phenotype and function of the enteric nervous system. J Physiol (Lond) 2014;592:2959-65.

doi:10.1113/jphysiol.2014.272948

40 Malumbres M, Harlow E, Hunt T, et al. Cyclin-dependent kinases: a family portrait. Nature Cell Biology 2009;11:1275-6. doi:10.1038/ncb1109-1275

41 Taché Y, Garrick T, Raybould H. Central nervous system action of peptides to influence gastrointestinal motor function. Gastroenterology 1990;98:517-28. doi:10.1016/00165085(90)90849-v

42 Stengel A, Taché Y. Neuroendocrine control of the gut during stress: corticotropinreleasing factor signaling pathways in the spotlight. Annu Rev Physiol 2009;71:219-39. doi:10.1146/annurev.physiol.010908.163221

43 Fond G, Loundou A, Hamdani N, et al. Anxiety and depression comorbidities in irritable bowel syndrome (IBS): a systematic review and meta-analysis. Eur Arch Psychiatry Clin Neurosci 2014;264:651-60. doi:10.1007/s00406-014-0502-z 
medRxiv preprint doi: https://doi.org/10.1101/2020.06.17.20132555; this version posted June 19, 2020. The copyright holder for this preprint (which was not certified by peer review) is the author/funder, who has granted medRxiv a license to display the preprint in perpetuity.

It is made available under a CC-BY-NC-ND 4.0 International license .

\section{FIGURE LEGENDS}

609 Figure 1. Manhattan plot of STL-FRQ GWAS meta-analysis results. GWAS

610 association signals $\left(-\log _{10} \mathrm{P}\right)$ are reported for SNP markers across all chromosomes

611 shown in alternate gray colors. Significance level corresponding to genome wide

$612\left(P=5.0 \times 10^{-8}\right)$ threshold is indicated with a dashed red horizontal line. For each

613 independent association signal, the nearest gene (within 100kb, otherwise the lead

614 SNP) is reported. Genome-wide significant markers are highlighted in green.

615 Figure 2. Gene set enrichment analysis results. Top significant findings from

616 GeneNetwork analysis ranked by $-\log _{10}$ FDR adjusted P and color-coded according

617 to KEGG pathways, Gene Ontology biological process (GOBP) and molecular

618 function (GOMF) categories.

619 Figure 3. Heatmap of STL-FRQ gene expression in colonic cells. A selection of

$620 S T L-F R Q$ genes is reported for their expression in relevant cell types from colonic 621 mucosa and colonic muscularis, ordered according to increasing expression. The 622 heatmap displays log2(TP10K+1) transformed data, and the expression of each gene 623 is scaled across all cells and shown in color scale ranging from 0 to the 99th data 624 quantile (to avoid high/low expressed genes dominating the heatmap). ICCs: 625 interstitial cells of Cajal; PSN: putative sensory neurons; PEMN: putative excitatory 626 motor neurons; PIMN: putative inhibitory motor neurons; PIN: putative interneurons; 627 PSVN: secretomotor/vasodilator neurons. Cell types, neuron types and subtypes are 628 classified as defined previously in Drokhlyansky et al. (Ref [20]).

629 Figure 4. Cross-trait analysis of STL-FRQ GWAS results. A) Circus plot showing 630 previously reported genome-wide significant associations $\left(P=5.0 \times 10^{-8}\right)$ at the 13 631 STL-FRQ loci (lead SNPs or r2>0.8 LD proxies, see Methods). Associations are 
medRxiv preprint doi: https://doi.org/10.1101/2020.06.17.20132555; this version posted June 19, 2020. The copyright holder for this preprint (which was not certified by peer review) is the author/funder, who has granted medRxiv a license to display the preprint in perpetuity.

It is made available under a CC-BY-NC-ND 4.0 International license .

632 grouped by category, and the ribbon size is proportional to the number of associated

633 traits in that category. In order to avoid redundancy, for multiple markers (lead or

634 proxy SNP) linked to the same trait only the one with the lowest $P$ is reported. No

635 association were detected for 3 loci. B) Results obtained in the LDSC analyses of

636 genetic correlation, in relation to a selection of most relevant traits (full results

637 reported in Supplementary Table 7).

638 Figure 5. STL-FRQ polygenic scores (PGS) and IBS in UK Biobank. Results are

639 reported (including statistical significance) in relation to PGS distribution in IBS cases

640 vs controls (left panels, P-values from t-test), and in relation to the prevalence of IBS

641 across PGS percentiles in the entire cohort (right panels; with top $5 \%$ of the

642 distribution highlighted with shaded area, P-values vs the rest of the cohort from

643 logistic regression). IBS and subtypes defined according to Rome III Criteria based

644 on DHQ questionnaire data (see Methods). 
Table 1. STL-FRQ GWAS meta-analysis and fine mapping results

\begin{tabular}{|c|c|c|c|c|c|c|c|c|c|}
\hline Chr & Lead SNP & Start-end (bp) & EA & OA & EAF & Beta (SE) \# & $\mathbf{P}$ & $\begin{array}{l}\text { Nearest gene } \\
\text { (other genes) * }\end{array}$ & $\begin{array}{c}\text { Most likely causal SNP } \\
(\% \text { probability })^{\wedge}\end{array}$ \\
\hline 1 & rs11240503 & $205469956-205485290$ & $A$ & $\mathrm{G}$ & 0.300 & $0.018(0.003)$ & $7.8 \mathrm{E}-09$ & CDK18 (5) & $\underline{\mathrm{rs} 11240503}(0.588)$ \\
\hline 5 & rs39819 & $122032544-122636855$ & $A$ & $\mathrm{G}$ & 0.671 & $0.018(0.003)$ & $1.2 \mathrm{E}-09$ & SNX24 (3) & - \\
\hline 5 & rs 13162291 & $154119471-154448827$ & $A$ & $\mathrm{G}$ & 0.191 & $0.020(0.004)$ & 2.7E-08 & MRPL22 (5) & $\underline{\operatorname{rs} 13162291}(0.835)$ \\
\hline 7 & rs12700026 & $2554037-2605424$ & $A$ & $\mathrm{C}$ & 0.890 & $-0.029(0.005)$ & $1.4 \mathrm{E}-10$ & LFNG (5) & rs 12700026, rs $12700027(0.350)$ \\
\hline 7 & rs4556017 & $99919517-100678086$ & $\mathrm{~T}$ & $\mathrm{C}$ & 0.853 & $0.024(0.004)$ & $1.0 \mathrm{E}-09$ & MUC12 (46) & $\underline{\mathrm{rs} 4556017}(0.951)$ \\
\hline 8 & rs10957534 & 71482998-72012331 & $\mathrm{C}$ & $\mathrm{G}$ & 0.367 & $-0.016(0.003)$ & $1.3 \mathrm{E}-08$ & (5) & - \\
\hline 11 & rs6486216 & $14980848-15127148$ & $\mathrm{~T}$ & $\mathrm{C}$ & 0.276 & $0.018(0.003)$ & $1.1 \mathrm{E}-08$ & CALCB (5) & - \\
\hline 11 & rs12273363 & $27455582-27748493$ & $\mathrm{~T}$ & $\mathrm{C}$ & 0.795 & $0.032(0.003)$ & $4.8 \mathrm{E}-21$ & BDNF (3) & $\underline{\operatorname{rs} 12273363}(0.525)$ \\
\hline 12 & rs11176001 & $66317487-66410673$ & $A$ & C & 0.132 & $0.034(0.004)$ & $1.6 \mathrm{E}-16$ & HMGA2 (1) & rs11176001 (0.392) \\
\hline 12 & rs10492268 & 98298807-98506148 & $\mathrm{T}$ & C & 0.552 & $0.016(0.003)$ & 1.6E-08 & (1) & rs10492268 (0.187) \\
\hline 12 & rs3858648 & $115861753-115950227$ & $A$ & C & 0.508 & $-0.016(0.003)$ & $1.2 \mathrm{E}-08$ & & rs3858648 (0.077) \\
\hline 17 & rs2732706 & $43460181-44865603$ & $\mathrm{~T}$ & C & 0.221 & $0.024(0.003)$ & $4.4 \mathrm{E}-12$ & ARL17A (109) & - \\
\hline 22 & rs5757162 & $38869463-39152412$ & $\mathrm{~T}$ & C & 0.286 & $0.017(0.003)$ & 4.0E-08 & FAM227A (21) & - \\
\hline
\end{tabular}

Chr: chromosome, EA: effect allele; OA: other allele; EAF: effect allele frequency

$\#$ positive beta $=$ higher stool frequency

* nearest gene (within 100kb from lead SNP) and other genes in the region, based on FUMA positional and eQTL mapping

$\wedge$ only causal SNPs identified with $>5 \%$ probability are reported (>50\% underlined) 
medRxiv preprint doi: https://doi.org/10.1101/2020.06.17.20132555; this (which was not certified by peer review) is the author/funder, who granted medRxiv a license to display the preprint in perpetuity. It is made available under a CC-BY-NE-ND 4.0 International license.
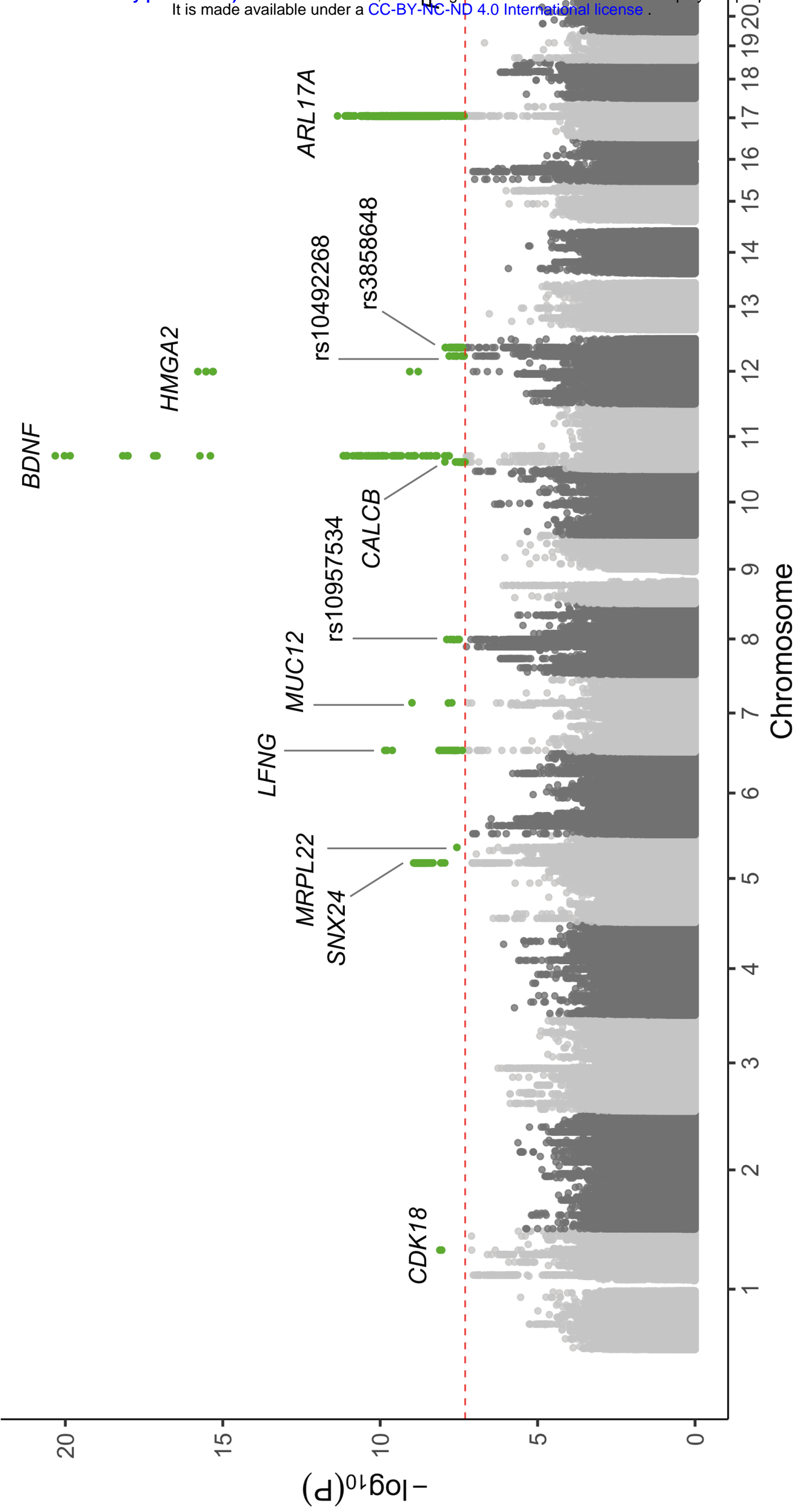

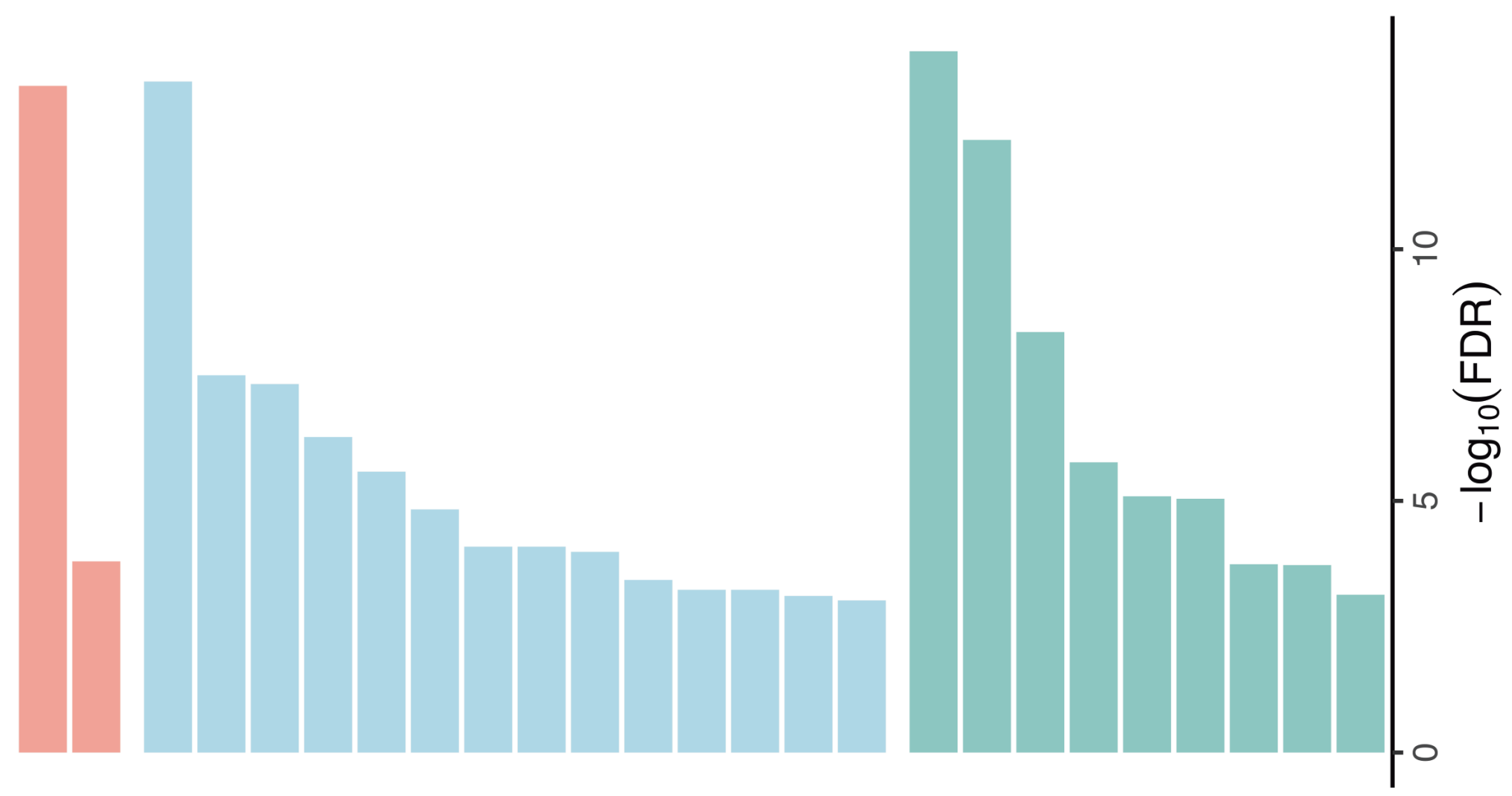

ЭЭヨУ

dgO९

$\exists$ WOS

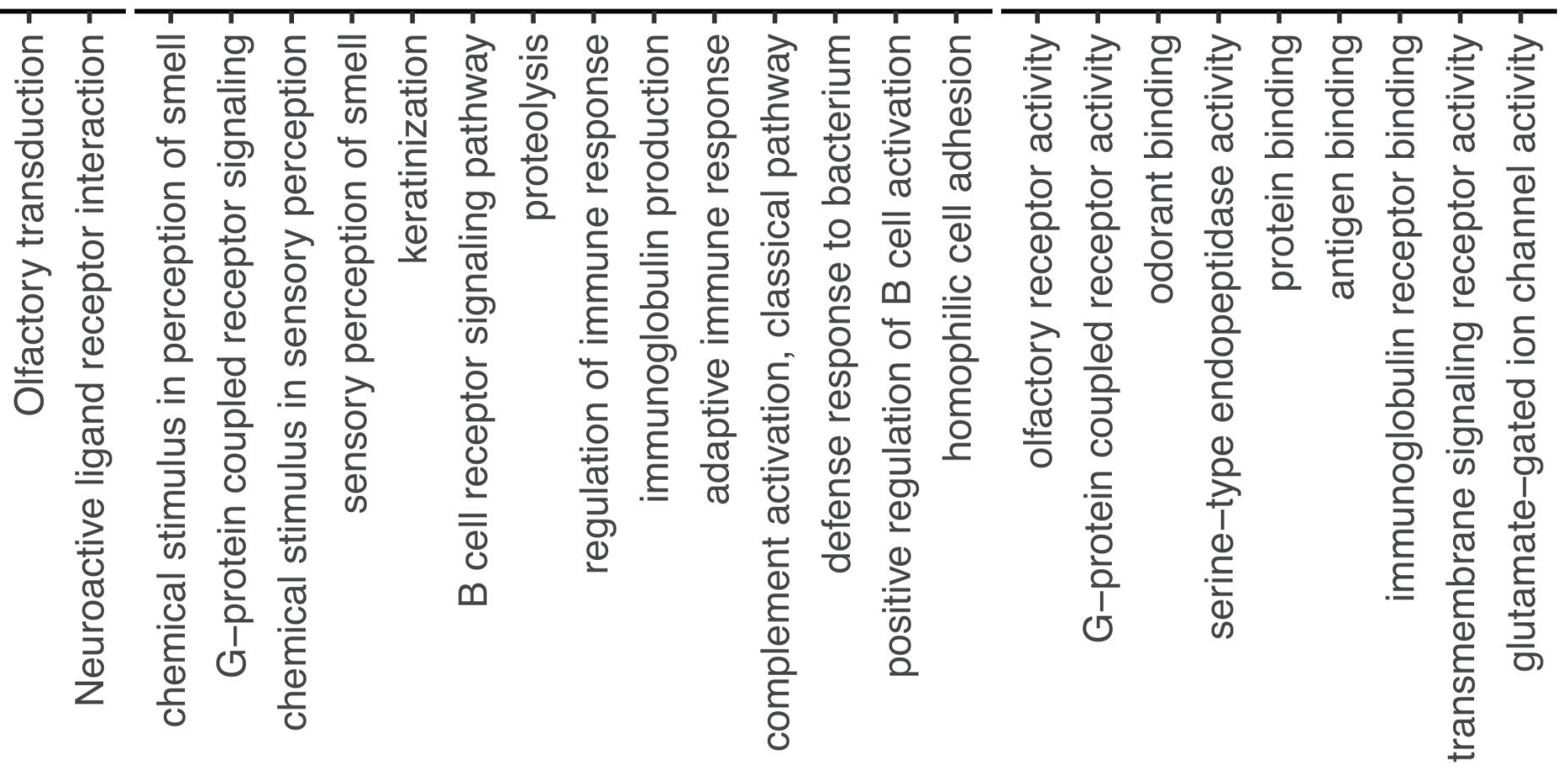


$\nabla \quad N \quad 0$

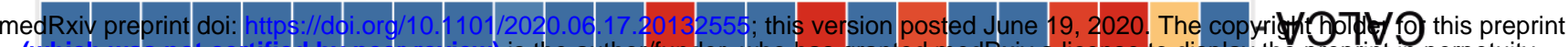

(which_was_not_certified_by_peetr_eview) is the author/funder, who has-granted medBxiv a-license-to display the preprint in perpetuity - $807 \forall 0$

$-\perp d \forall W$

- てコヨגW

- $\varepsilon d \forall \supset \forall$

- ヨН

- ¿Sdり

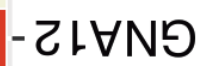

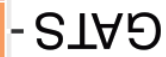

$-9 \times 80$

- $\nabla \Gamma N O Y$

- Ld $\forall 7$

- IWHYᄏ7d

- $\exists$ OO

- LAdOO

- I甘LO7S

- nvld

- เசНபல

- $\nabla$ ZXNS

- Id人OH

- ¿つवX $\forall \exists$

- gy기

- L TSN $\forall Y$

- $\lrcorner$ NOG

- LIXOO

- ટ밉

- เาเ

- 81Y्रOO

- $8 \angle\llcorner 74 \forall$

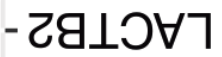

- 9๑甘8

- LASOR

- LIONW

- ટเOกW

- Eつつタ甘

- 86 เнО

- ENNO

- $\forall$ 기머

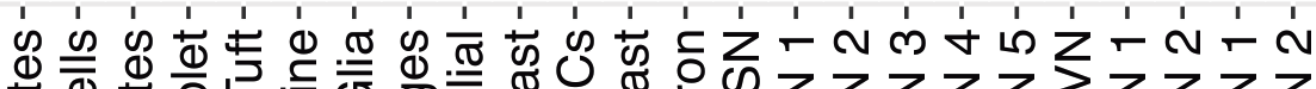

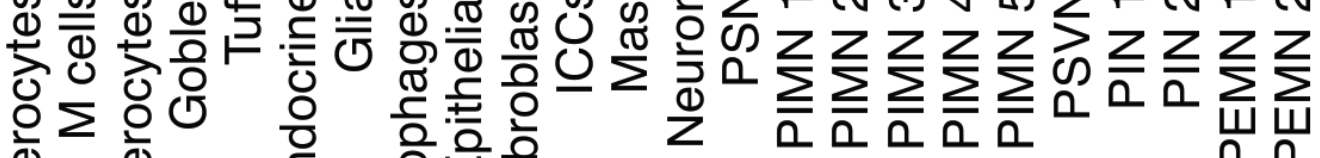

产

은 느는

$\overline{\mathrm{a}} \overline{\mathrm{a}} \overline{\mathrm{a}} \overline{\mathrm{a}}$

뜨믐

亡

$+\quad \stackrel{\frac{0}{ \pm}}{ \pm} \quad \sum$

$\stackrel{+}{ \pm} \quad \frac{+}{c}$ 
medRxiv preprint doi: https://doi.org/10.1101/2020.06.17.20132555; this version posted June 19, 2020. The copyright holder for this preprint (which was not certified by peer review) is the author/funder, who has granted medRxiv a license to display the preprint in perpetuity.
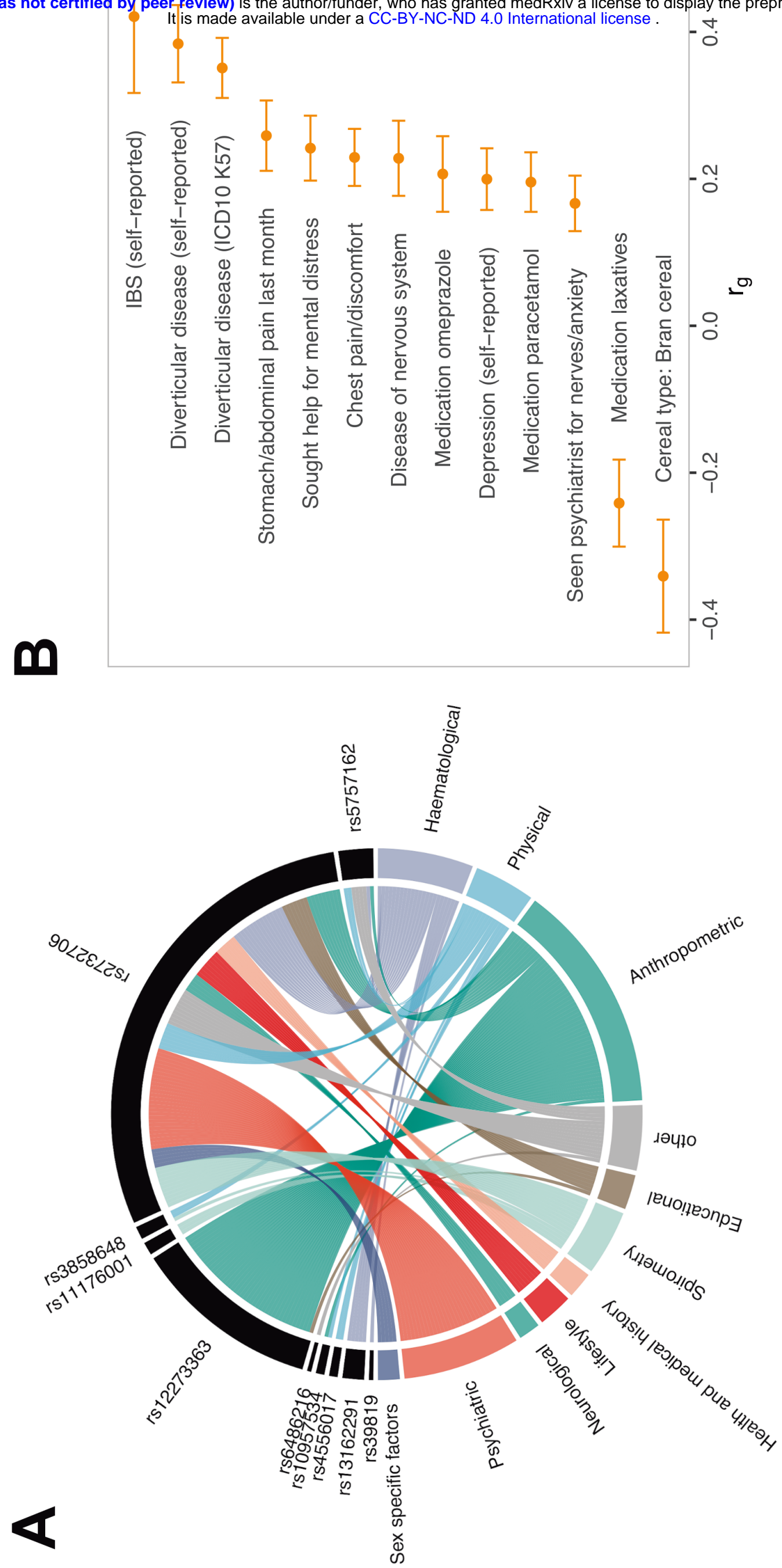


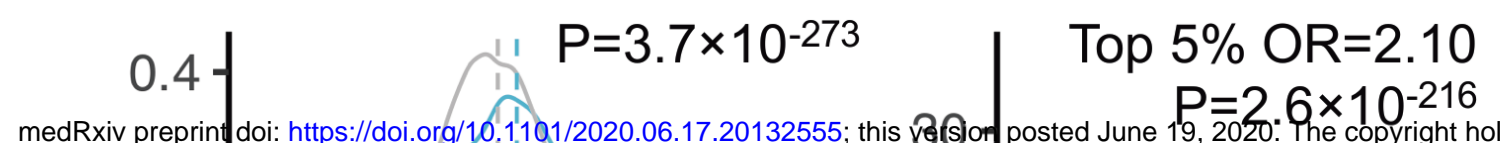

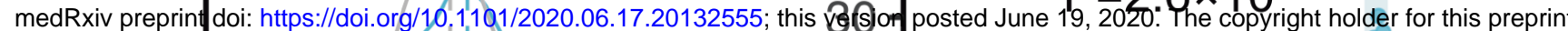
(which was ndt certified by peer review) is the author/funder, whyhas granted medRxiv a license to display the preprint in perpetuity.
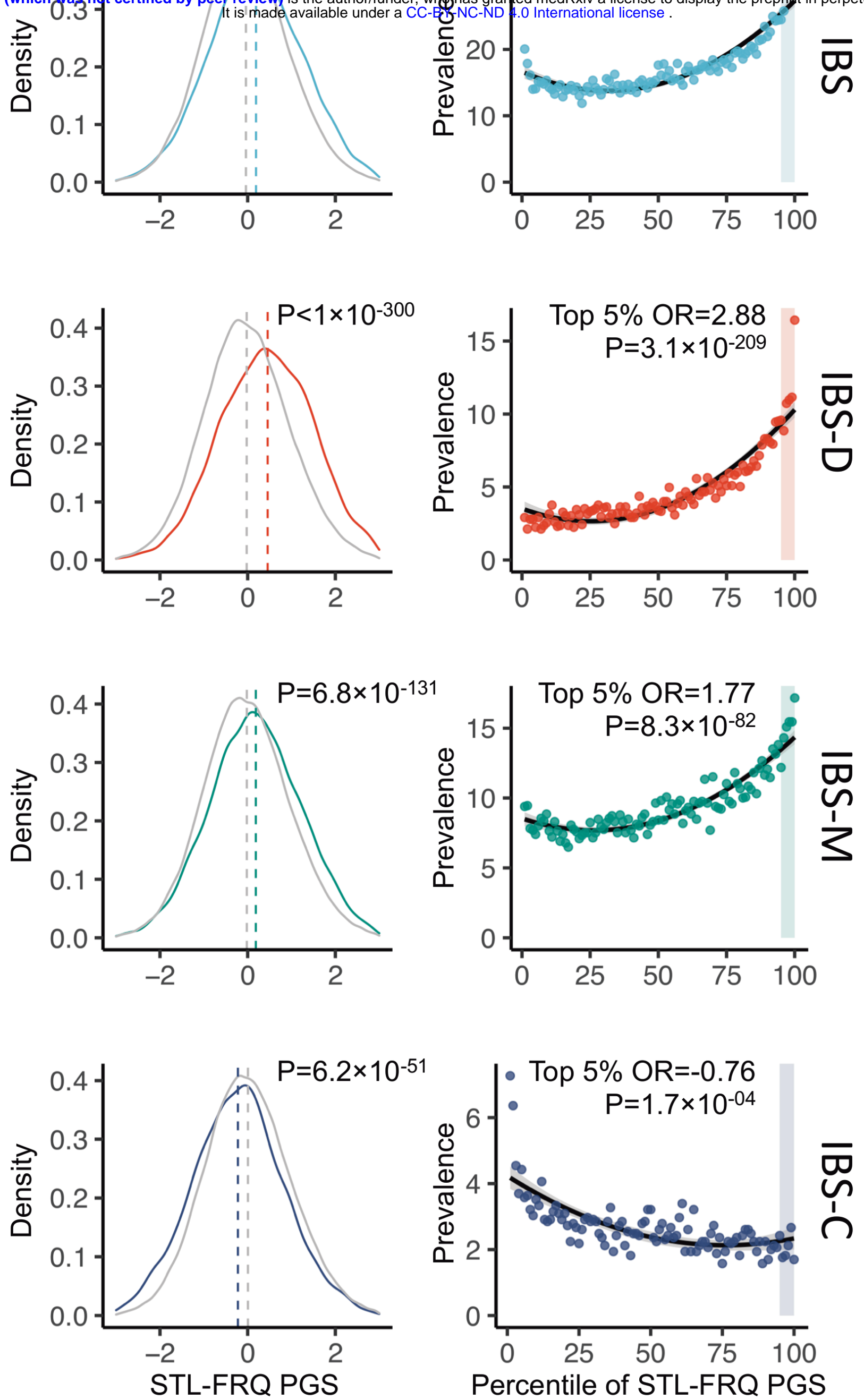